\title{
MANAJEMEN MUTU TERHADAP PENINGKATAN KUALITAS LEMBAGA PENDIDIKAN ISLAM
}

\author{
Mila Mahmudah \\ STAI Taruna Surabaya
}

Email milamahmudah91495@gmail.com

\begin{abstract}
The term management has many meanings, management is directing / leading something of effort through planning, organizing, coordinating and controlling human resources and materials aimed at achieving predetermined goals. In the science of management there is the concept of problem solving that is placed in the workplace, namely the P-D-C-A approach as a process of solving problems with a continuous and systematic pattern. While management can also be defined as a process of organizing and utilizing the resources of the organization through the cooperation of members to achieve organizational goals effectively and efficiently. The practice of organizing education can be analogous to the production process in a company (industry). It's just that the products produced by educational institutions in the form of services. Therefore educational institutions can be said as service companies. From this perspective, the quality and quality of services (services) produced is a measure of the quality of an educational institution. Namely the extent of customer satisfaction with the services produced. What is meant by customers here are internal customers, namely teachers and other education personnel, and external customers, namely students and related parties outside the educational institution. Thus, schools are said to be of good quality if they are able to provide services according to or even exceed the expectations of teachers, employees, students, and other related parties such as parents, funders, the government or the world of work of users of graduates.
\end{abstract}

Keywords: quality management, educational institutions 


\section{Pendahuluan}

Upaya peningkatan mutu pendidikan merupakan titik strategis dalam upaya menciptakan pendidikan yang berkualitas. Pendidikan yang berkualitas merupakan salah satu pilar pembangunan bagi suatu bangsa melalui pengembangan potensi individu. Karenanya, dapat dikatakan bahwa masa depan suatu bangsa terletak pada mutu dan kualitas pendidikan yang dilaksanakan. Untuk menjamin mutu dan kualitas pendidikan, diperlukan perhatian yang serius, baik oleh penyelenggaran pendidikan, pemerintah, maupun masyarakat. Sebab, dalam sistem pendidikan nasional sekarang ini, konsentrasi terhadap mutu dan kualitas bukan semata-mata tanggungjawab sekolah dan pemerintah, tetapi merupakan sinergi antara berbagai komponen termasuk masyarakat.

Oleh karena itu, masyarakat harus sadar dan berkonsentrasi terhadap peningkatan mutu pendidikan. Untuk melaksanakan penjaminan mutu tersebut, diperlukan kegiatan yang sistematis dan terencana dalam bentuk manajemen mutu. Manajemen mutu dalam pendidikan merupakan cara dalam mengatur semua sumber daya pendidikan, yang diarahkan agar semua orang yang terlibat di dalamnya melaksanakan tugas dengan penuh semangat dan berpartisipasi dalam perbaikan pelaksanaan pekerjaan sehingga menghasilkan jasa yang sesuai bahkan melebihi harapan pelanggan.

Menurut Mulyasa, sebagai industri jasa, mutu lembaga pendidikan dapat diukur dari pelayanan yang diberikan oleh pengelola pendidikan beserta seluruh karyawan kepada para pelanggan sesuai dengan standar mutu tertentu, bukan hanya dalam bentuk kualitas lulusannya. Pendidikan yang bermutu tidak dapat hanya dilihat dari kualitas lulusannya, tetapi juga mencakup bagaimana lembaga pendidikan mampu memenuhi dan melayani kebutuhan pelanggan sesaui dengan standar mutu yang berlaku.

Untuk menjamin pelaksanaan standarisasi mutu dan kualitas pendidikan, manajemen mutu mempunyai peranan penting. Sebab, kegiatan dalam manajemen mutu bukan sekedar berupaya agar produk yang dihasilkan memenuhi standar mutu, tetapi lebih difokuskan pada bagaimana proses produksi bisa terlaksana dengan baik, sesuai dengan prosedur yang seharusnya dilakukan agar dapat menghasilkan produk yang memuaskan pelanggan, khususnya masyarakat pengguna jasa pendidikan 


\section{Konsep Dasar Manajemen Mutu}

Di dalam ilmu manajemen ada konsep probllem solving yang ditempatkan di tempat kerja, yaitu pendekatan P-D-C-A sebagai proses penyelesaian masalah. P-D-C-A. pertama kali dikemukakan oleh Walter Shewhart. Dalam bahasa pengendalian kualitas, P-D-C-A dapat diartikan sebagai proses penyelesaian dan pengendalian masalah dengan pola runtun dan sistematis. ${ }^{1}$

Secara ringkas, proses P-D-C-A dapat dijelaskan sebagai berikut :

a. $\quad \mathrm{P}($ Plan $=$ Rencanakan $)$

Artinya merencanakan sasaran dan proses apa yang dibutuhkan untuk menentukan hasil yang ditetapkan. Plan harus diterjemahkan secara detail dan per sub-sitem.

1) Perencanaan ini dilakukan untuk mengidentifikasi sasaran dan poses dengan mencari tahu hal-hal apa saja yang tidak beres kemudian mencari solusi dan ide-ide untuk memecahkan masalah

2) Mengacu pada aktivitas identifikasi peluang perbaikan dan/atau identifikasi terhadap cara-cara mencapai peningkatan dan perbaikan

3) Terakhir mencari dan memilih penyelesaian masalah.

b. $\quad$ D $($ Do $=$ kerjakan $)$

Artinya melakukan perencanaan proses yang telah ditetapkan sebelumnya. Ukuran-ukuran proses ini juga telah ditetapkan dalam tahap PLAN. Dalam konsep DO ini kita harus benar-benar menghindari penundaan, semakij kita menunda pekerjaan semakin terbuang dan yang pasti pekerjaan akan bertambah banyak.

Dalam langkah ini, yaitu

1) melaksanakan rencana yang telah disusun sebelumnya dan memantau proses pelaksanaan dalam skala kecil (uji coba).

2) mengacu pada penerapan dan pelaksanaan aktivitas yang direncanakan.

\footnotetext{
${ }^{1}$ https//sites.google.com
} 
c. $\quad \mathrm{C}($ Chek $=$ evaluasi $)$

Artinya melakukan evaluasi terhadap sasaran dan proses serta melaporkan apa saja hasilnya. Kita mengecek kembali apa yang sudah kita kerjakan, sudahkah sesuai dengan standart yang ada atau masih ada kekurangan.

1) Memantau dan mengevaluasi proses dan hasil terhadap sasaran dan spesifikasi dan melaporkan hasilnya.

2) Dalam pengecekan ada dua hal yang perlu diperhatikan, yaitu memantau dan mngevaluasi proses dan hasil terhadap sasaran dan spesifikasi.

3) Teknik yang digunakan adalah observasi dan survei. Apabila masih menemukan kelemahan-kelemahan, maka disusunlah rencana perbaiakan untuk dilaksanakan selanjutnya. Jika gagal, maka cari pelaksanaan lain, namun jika berhasil dilakukan rutinitas.

4) Mengacu pada verifikasi apakah penerapan tersesbut sesuai dengan rencana peningkatan dan perbaikan yang diinginkan.

d. $\quad$ A (act $=$ menindaklanjuti $)$

Artinya melakukan evaluasi total terhadap Hasil sasaran dan proses dan menindaklanjuti dengan perbaikan-perbaikan. Jika ternyata apa yang telah kita kerjakan masih ada yang kurang atau belum sempurna, segera lakukan action untuk memperbaiki, proses ACT ini sangat penting artinya sebelum kita melangkah lebih jauh ke proses perbaikan selanjutnya.

1) Menindaklanjuti hasil untuk membuat perbaikan yang diperlukan. Ini berarti juga meninjau seluruh langkah dan memodifikasi proses untuk memperbaiaki sebelum implementasi selanjutnya.

2) Menindak lanjuti hasil berarti melakukan standarisasi perubahan, seperti mempertimbangkan area mana saja yang mungkin diterapkan, merevisi proses yang sudah diperbaiki, melakukan modifikasi standart, prosedur dan kebijakan yang ada, mengkomunikasikan kepada seluruh staf, prosedur dan kebijakan yang ada, mengembangkan rencana yang jelas, dan mendokumentasikan proyek. 
Istilah manajemen memiliki banyak arti, tergantung orang yang mengartikannya. Menurut Moefti Wiriadihardja, manajemen adalah mengarahkan/memimpin sesuatu daya usaha melalui perencanaan, pengorganisasian, pengkordinasian dan pengendalian sumber daya manusia dan bahan ditujukan untuk mencapai tujuan yang telah ditentukan sebelumnya. $^{2}$ Sedang Syafaruddin mendefinisikan manajemen sebagai suatu proses pengaturan dan pemanfaatan sumber daya yang dimiliki organisasi melalui kerjasama para anggota untuk mencapai tujuan organisasi secara efektif dan efisien. ${ }^{3}$

Dari dua pengertian di atas, dapat dipahami bahwa manajemen merupakan tindakantindakan yang dilakukan oleh sekelompok orang dalam sebuah organisasi dalam rangka mencapai tujuan organisasi yang telah ditetapkan. Sedangkan mutu, secara essensial digunakan untuk menujukkan kepada suatu ukuran penilaian atau penghargaan yang diberikan atau dikenakan kepada barang (product) dan/atau jasa (service) tertentu berdasarkan pertimbangan obyektif atas bobot dan/atau kinerjanya. ${ }^{4}$ Jasa/pelayanan atau produk tersebut dikatakan bermutu apabila minimal menyamai bahkan melebihi harapan pelanggan. Dengan demikian, mutu suatu jasa maupun barang selalu berorientasi pada kepuasaan pelanggan. Apabila kata mutu digabungkan dengan kata pendidikan, berarti menunjuk kepada kualitas product yang dihasilkan lembaga pendidikan atau sekolah. Yaitu dapat diidentifikasi dari banyaknya siswa yang memiliki prestasi, baik prestasi akademik maupun yang lain, serta lulusannya relevan dengan tujuan. ${ }^{5}$

Dari penjelasan di atas, dapat disimpulkan bahwa manajemen mutu adalah suatu cara dalam mengelola suatu organisasi yang bersifat komprehensif dan terintegrasi yang diarahkan dalam rangka memenuhi kebutuhan pelanggan secara konsisten dan mencapai peningkatan secara terus menerus dalam setiap aspek aktivitas organisasi. Sasaran yang dituju dari manajemen mutu adalah meningkatkan mutu pekerjaan, memperbaiki prodiktivitas dan efisiensi melalui perbaikan kinerja dan peningkatan mutu kerja agar menghasilkan produk yang memuaskan atau memenuhi kebutuhan pelanggan. Jadi, manajemen mutu bukanlah

\footnotetext{
${ }^{2}$ Wiriadihardja, Moefti, Dimensi Kepemimpinan dalam Manajemen (Jakarta: Balai Pustaka, 1987), 30.

${ }^{3}$ Syafaruddin, Manajemen Lembaga Pendidikan Islam (Jakarta: Ciputat Press, 2005), 42

${ }^{4}$ Aan Komariah dan Cepi Tiratna, Visionary Leadership, Menuju Sekolah Efektif. (Jakarta: Bumi Aksara, 2005), 9.

${ }^{5}$ Ibid., 8 .
} 
seperangkat peraturan dan ketentuan yang kaku yang harus diikuti, melainkan seperangkat prosedur proses untuk memperbaiki kinerja dan meningkatkan mutu kerja. ${ }^{6}$

Dalam manajemen produksi ada suatu mekanisme penjaminan agar produk yang dihasilkan dapat memenuhi standar mutu. Untuk itu pengendalian mutu harus dilakukan sejak awal perencanaan. Apabila pengendalian mutu dilakukan setelah produk dihasilkan bisa menghadapi resiko terjadinya sejumlah produk yang tidak sesuai dengan standar yang diharapkan. Dalam paradigma demikian, tujuan utama manajemen mutu adalah untuk mencegah dan mengurangi resiko terjadinya kesalahan dalam proses produksi, dengan cara mengusahakan agar setiap langkah yang dilaksankan selama proses produksi dapat berjalan sebaik-baiknya sesuai standar.

Dengan demikian dalam manajemen mutu bukan sekedar berupaya agar produk yang dihasilkan memenuhi standar mutu, tetapi lebih difokuskan pada bagaimana proses produksi bisa terlaksana dengan baik, sesuai dengan prosedur yang seharusnya dilakukan. Dengan proses produksi yang baik, tentu akan dapat menghasilkan produk yang baik pula.

\section{Manajemen Mutu Pendidikan}

Pendidikan yang bermutu dan berkualitas merupakan harapan dan dambaan bagi setiap warga negara ini. Masyarakat, baik yang terorganisir dalam suatu lembaga pendidikan, maupun orang tua/wali murid, sangat berharap agar murid dan anak-anak mereka mendapatkan pendidikan yang bermutu agar kelak dapat bersaing dalam menjalani kehidupan. Untuk menjawab harapan masyarakat tersebut, setiap lembaga pendidikan hendaknya selalu berupaya agar pendidikan yang dikelolanya dapat menghasilkan produk yang berkualitas, yaitu produk yang dapat memuaskan para pelanggan.

Praktek penyelenggaraan pendidikan dapat dianalogikan dengan proses produksi dalam sebuah perusahaan (industri). Hanya saja, produk yang dihasilkan lembaga pendidikan dalam bentuk jasa. Oleh karena itu lembaga pendidikan dapat dikatakan sebagai perusahaan jasa. $^{7}$ Dari prespektif ini, mutu dan kualitas layanan (jasa) yang dihasilkan merupakan ukuran mutu sebuah lembaga pendidikan. Yaitu sejauh mana kepuasaan pelanggan terhadap jasa yang dihasilkan.

\footnotetext{
${ }^{6}$ Mohammad Ali, "Penjaminan Mutu Pendidikan" dalam Mohammad Ali, Ibrahim, R., Sukmadinata, N.S., Sudjana, D., dan Rasjidin, W. (Penyunting), Ilmu dan Aplikasi Pendidikan. Jilid II (Bandung: Pedagogiana Press. 2007), 344.

${ }^{7}$ Ibid., 346.
} 
Menurut Mulyasa, sebagai industri jasa, mutu lembaga pendidikan dapat diukur dari pelayanan yang diberikan oleh pengelola pendidikan beserta seluruh karyawan kepada para pelanggan sesuai dengan standar mutu tertentu, bukan hanya dalam bentuk kualitas lulusannya. Pendidikan yang bermutu tidak dapat hanya dilihat dari kualitas lulusannya, tetapi juga mencakup bagaimana lembaga pendidikan mampu memenuhi dan melayani kebutuhan pelanggan sesaui dengan standar mutu yang berlaku.

Yang dimaksud pelanggan di sini adalah pelanggan internal, yaitu guru dan tenaga kependidikan lainya, dan pelanggan eksternal yaitu peserta didik dan pihak-pihak terkait di luar lembaga pendidikan tersebut. ${ }^{8}$ Dengan demikian, sekolah dikatakan bermutu apabila mampu memberi layanan sesuai atau bahkan melebihi harapan guru, karyawan, peserta didik, dan pihak-pihak lain yang terkait seperti orang tua, penyandang dana, pemerintah atau dunia kerja pengguna lulusan.

Untuk memberikan jaminan terahadap mutu dan kualitas, lembaga pendidikan harus mengetahui dengan pasti apa yang dibutuhkan oleh pelanggannya. Lembaga pendidikan hendaknya selalu berupaya mensinergikan berbagai komponen untuk melaksanakan manajemen mutu pendidikan yang dikelolanya agar dapat menjalankan tugas dan fungsi kependidikan. Untuk itu, kerjasama dengan semua komponen sekolah dalam manajemen harus menjadi prioritas. Komponen sekolah dimaksud adalah para pendidik, karyawan, peserta didik, orang tua/wali, maupunmasyarakat. Kerjasama dengan komponen sekolah dimaksudkan untuk melibatkan dan memberdayakan mereka dalam proses organisasi baik dalam pembuatan keputusan mupun pemecahan masalah.

Oleh karena itu, pada saat ini telah mengejala hampir di seluruh dunia sebuah cara untuk meningkatkan mutu pendidikan yaitu school based management yang di Indonesia dikenal dengan istilah Manajemen Berbasis Sekolah (MBS). Pada sistem MBS, sekolah dituntut secara mandiri untuk menggali, mengalokasikan, menentukan prioritas, mengendalikan, dan mempertanggungjawabkan pemberdayaan sumber-sumber, baik kepada masyarakat maupun pemerintah. ${ }^{9}$

Hal ini merupakan salah satu bentuk pembaharuan pendidikan, yang memberikan kewenangan penuh kepada sekolah untuk meneyelenggarakan pendidikan agar produk yang dihasilkan sesuai dengan lingkungan. Kecuali pemberian kewenangan yang cukup besar

\footnotetext{
${ }^{8}$ Mulyasa, E., Menjadi Kepala Sekolah Profesional, Cet. Ke-5 ( Bandung: PT. Remaja Rosdakarya, 2005 ), 266.

${ }^{9}$ HA.Mukti Ali Beberapa Madrasah Pendidikan di Indonesia (Yogyakarta :Yayasan Nida 1971),24.
} 
tersebut, pelaksanaan MBS juga memberikan beban pertanggungjawaban pengelolaan sumber daya yang ada kepada sekolah yang bersangkutan. Karena itu, MBS menekankan keterlibatan maksimal berbagai pihak, sehingga menjamin partisipasi semua komponen pendidiikan yang lebih luas dalam perumusan-perumusan keputusan tentang pendidikan. Hal ini dimaksudkan untuk mendorong komitmen mereka terhadap penyelenggaraan pendidikan. Yang pada akhirnya akan mendukung efektivitas dalam pencapaian tujuan sekolah. ${ }^{10}$

Keberhasilan manajemen mutu dalam dunia pendidikan (sekolah) dapat diukur tingkat kepuasaan pelanggan. Sekolah dapat dikatakan berhasil jika mampu memberikan layanan sesuai harapan pelanggan. Menurut Depdiknas (1999), sebagaimana dikutip Syafaruddin menyebutkan 4 (empat) hal yang merupakan cakupan keberhasilan manajemen sekolah, yaitu

a. Siswa puas dengan layanan sekolah, yaitu dengan pelajaran yang diterima, perlakuan guru, pimpinan, puas dengan fasilitas yang disediakan sekolah atau siswa menikmati situasi sekolah dengan baik.

b. Orang tua siswa merasa puas dengan layanan terhadap anaknya, layanan yang diterimanya dengan laporan tentang perkembangan kemajuan belajar anaknya dan program yang dijalankan sekolah

c. Pihak pemakai lulusan puas karena menerima lulusan dengan kualitas tinggi dan sesuai harapan, dan

d. Guru dan karyawan puas dengan layanan sekolah, dalam bentuk pembagian kerja, hubungan dan komunikasi antar guru/pimpinan, karyawan, gaji/honor yang diterima dan pelayanan.

Undang-Undang No. 22 Tahun 1999 tentang Otonomi Daerah membawa dampak pada pengelolaan pendidikan di daerah, dengan diberlakukannya desentralisasi pendidikan. Dengan diberlakukannya otonomi pendidikan, diharapkan akan berpengaruh positif terhadap tumbuhnya lembaga pendidikan yang berkualitas. Setiap lembaga pendidikan diharapkan mampu menggali sumber daya dan potensi daerah berbasis keunggulan lokal.

Konsekuensi yang tidak bisa dihindarkan dari desentralisasi pendidikan tersebut, karena budaya dan potensi daerah yang sangat beragam, adalah lulusan yang bervariasi. Oleh karena itu, upaya standarisasi mutu dan jaminan bahwa penyelenggaraan pendidikan

\footnotetext{
${ }^{10}$ Ibid. 26.
} 
memenuhi standar mutu harus menjadi fokus perhatian dalam upaya memelihara dan meningkatkan mutu pendidikan secara nasional. ${ }^{11}$

Mohammad Ali memaparkan, bahwa untuk menjamin terselenggaranya pendidikan sesuai dengan standar mutu, diperlukan penilaian secara terus menerus dan berkesinambungan terhadap kelayakan dan kinerja yang dilakukan dalam rangka melakukan pebaikan dan peningkatan mutu sekolah. Penilaian terhadap kelayakan dan kinerja secara berkesinambungan tesebut tidak dapat dilepaskan kaitannya dengan manajemen, khususnya manajemen mutu sekolah, yang mempunyai tujuan utama mencegah dan mengurangi resiko terjadinya kesalahan dalam proses produksi, dengan cara mengusahakan agar setiap langkah yang dilaksankan selama proses produksi dapat berjalan sebaik-baiknya sesuai standar. ${ }^{12}$

Dari paparan di atas, dapat ditarik pemahaman bahwa untuk menjamin pelaksanaan standarisasi mutu dan kualitas pendidikan, manajemen mutu mempunyai peranan penting. Sebab, kegiatan dalam manajemen mutu bukan sekedar berupaya agar produk yang dihasilkan memenuhi standar mutu, tetapi lebih difokuskan pada bagaimana proses produksi bisa terlaksana dengan baik, sesuai dengan prosedur yang seharusnya dilakukan agar dapat menghasilkan produk yang memuaskan pelanggan, khususnya masyarakat pengguna jasa pendidikan.

\section{Manajemen Mutu di Madrasah}

Pada masa awal berdirinya, sebagian madrasah di Indonesia masih lebih banyak memberikan ilmu-ilmu keagamaan daripada ilmu-ilmu umum. Namun terjadilah perubahan yaitu setelah keluarnya Surat Keputusan Bersama Tiga Menteri ( SKB 3 Menteri) yaitu Menteri Agama, Menteri Pendidikan dan Kebudayaan, dan Menteri Dalam Negeri : maka semua madrasah mengubah kurikulumnya menjadi $70 \%$ bidang studi umum, dan $30 \%$ bidang studi agama. Hal ini berlaku bagi madrasah yang dikelola oleh Departemen Agama dalam hal ini madrasah negeri, sedangkan madrasah yang dikelola swasta ada beberapa variasi yakni

\footnotetext{
11 UU No 22 Tahun 1999

12 HA.Mukti Ali Beberapa Madrasah Pendidikan di Indonesia (Yogyakarta :Yayasan Nida 1971), 342
} 
ada $60 \%$ bidang studi agama dan $40 \%$ bidang studi umum dan ada juga yang memang masih tetap yakni $70 \%$ bidang agama dan $30 \%$ bidang studi umum. ${ }^{13}$

Tujuan peningkatan mutu pendidikan pada madrasah adalah agar mata pelajaran umum dari madrasah mencapai tingkat yang sama dengan mata pelajaran umum disekolah umum yang setingkat. Agar mata pelajaran umum di madrasah mencapai tingkat mata pelajaran disekolah umum, dilakukan peningkatan-peningkatan di bidang ; ${ }^{14}$
a. Kurikulum
b. Buku pelajaran, alat pendidikan dan sarana pendidikan pada umumnya
c. Pengajar.

Dengan demikian berarti ;

a. Eksistensi madrasah sebagai lembaga pendidikan Islam menjadi mantap dan kuat.

b. Pengetahuan umum pada madrasah akan lebih baik

c. Adanya civil effect terhadap ijazah madrasah.

Untuk mencapai tujuan peningkatan mutu pendidikan umum pada madrasah ditentukan agar madrasah menyesuaikan pelajaran umum yang diberikan setiap tahun disemua tingkat sebagai berikut ;

a. Pelajaran umum di Madrasah Ibtidaiyah, sama dengan standar pengetahuan umum di Sekolah Dasar.

b. Pelajaran umum di Madrasah Tsanawiyah, sama dengan standar pengetahuan umum pada Sekolah Menengah Pertama.

c. Pelajaran umum pada Madrasah Aliyah, sama dengan standar pengetahuan umum pada Sekolah Menengah Atas. ${ }^{15}$

\section{Manajemen Mutu di Pondok Pesantren}

Pondok pesantren adalah salah satu bentuk lembaga pendidikan dan keagamaan yang ada di Indonesia. Secara lahiriyah, pesantren pada umumnya merupakan suatu komplek bangunan yang terdiri dari rumah kyai, masjid, pondok tempat tinggal para santri dan

\footnotetext{
${ }^{13}$ Prof. DR.HM. Ridlwan Nasir,MA Mencari Tipologi Format Pendidikan Islam (PUSTAKA PELAJAR Yogyakarta $2005), 91$

${ }^{14}$ Ibid hal 92

${ }^{15}$ Surat Keputusan Bersama Tiga Menteri tahun 1975 bab III
} 
ruangan belajar. Di sinilah para santri tinggal beberapa tahun belajar langsung dari kyai dalam satu hal ilmu agama. Meskipun dewasa ini pondok pesantren telah tumbuh dan berkembang secara bervariasi. ${ }^{16}$

Ada lima klasifikasi pondok pesantren menurut HA. Mukti Ali, yaitu ;

a. Pondok Pesantren Salaf/Klasik ; yaitu Pondok Pesantren yang didalamnya terdapat sistem pendidikan salaf (weton dan sorogan), dan sistem klasikal (madrasah) salaf.

b. Pondok Pesantren Semi berkembang, yaitu Pondok Pesantren yang didalamnya terdapat pendidikan salag dan sistem klasikal swasta dengan kurikulum $90 \%$ agama dan $10 \%$ umum.

c. Pondok Pesantren Berkembang, yaitu Pondok Pesantren seperti semi berkembang, hanya saja sudah lebih bervariasi dalam bidang kurikulumnya, yakni 70\% agama dan 30\% umum. Disamping itu juga diselenggarakan madrasah SKB Tiga Menteri dengan penambahan diniyah.

d. Pondok Pesantren Khalaf/Modern : yaitu seperti bentuk pondok pesantren berkembang, hanya saja sudah lebih lengkap lembaga pendidikan yang ada di dalamnya, antara lain diselenggarakan sistem pendidikan yang ada didalamnya, antara lain diselenggrakannya sistem sekolah umum dengan penambahan diniyah (praktek membaca kitab salaf), perguruan tinggi (baik umum maupun agama), bentuk koperasi dan dilengkapi sengan takhasus (bahasa Arab dan Inggris).

e. Pondok Pesantren Ideal, yaitu sebagaimana bentuk pondok pesantren modern hanya saja lembaga pendidikan yang ada lebih lengkap, terutama bidang ketrampilan yang meliputi pertanian, teknik, perikanan, perbankan, dan benarbanar memperhatikan kualitasnya dengan tidak menggeser ciri khusus kepesantrenannya yang masih relevan dengan kebutuhan masyarakat/perkembangan zaman. Dengan adanya bentuk tersebut diharapkan alumni pondok pesantren benar-banar berpredikat khalifah fil ardli.

Pondok pesantren yang ideal adalah pondok pesantren yang mampu mengantisipasi adanya pendapat yang mengatakan bahwa alumni pondok pesantren tidak berkualitas. Oleh sebab itu, sasaran utama yang diperbarui adalah

\footnotetext{
${ }^{16}$ Prof. DR.HM. Ridlwan Nasir,MA Mencari Tipologi Format Pendidikan Islam (PUSTAKA PELAJAR; Yogyakarta 2005), 81
} 
mental, yakni mental manusia dibangun hendaknya diganti dengan mental membangun. ${ }^{17}$.

Dengan memperbaiki mental ini, maka sudah barang tentu berakibat pembaharuan kurikulum pondok pesantren. Karena sampai saat ini , sebagian sistem pendidikan dan pengajaran pondok pesantren lebih banyak ditekankan kepada agama, mental dan intelek. Pendidikan Yang berhubungan dengan ketrampilan kerja tangan belum mendapat perhatian. Oleh sebab itu, perlu adanya peningkatan dalam memberikan pelajaran-pelajaran yang menimbulkan ketrampilan kerja tangan sehingga dapat melahirkan tenaga-tenaga produsen, bukan tenaga-tenaga konsumen. ${ }^{18}$

\section{Manajemen Mutu di Perguruan Tinggi Islam}

\section{a. Konsep dan Kedudukan Perguruan Tinggi}

Sistem pendidikan nasional dibangun melalui berbagai kelembagaan/ organisasi pendidikan yang berperan sebagai unit-unit yang melaksanakan sistem pendidikan dalam upaya untuk membangun bangsa. Lahirnya UU No. 20 tahun 2003 tentang sisdiknas menunjukan bahwa bangsa Indonesia menginginkan suatu manajemen pendidikan secara nasional yang tertata, terarah serta terstruktur dalam satu kesatuan, sehingga siapa pun dan di mana pun seseorang tinggal dapat menjadi bagi terintegrasi dalam berkontribusi bagi peningkatan mutu kehidupan bangsa melalui kesempatannya mengikuti pendidikan yang menyatukan dan memperkuat kesatuan serta persatuan bangsa. ${ }^{19}$

Qomar, membagi Perguruan Tinggi Agama Islam (PTAI) dari segi tanggung jawab pengelolaan, dibagi menjadi dua, yakni Perguruan Tinggi Agama Islam Negeri (PTAIN) dan Pergururuan Tinggi Agama Islam Swasta (PTAIS). PTAIN hampir sepenuhnya didanai pemerintah, sedangkan PTAIS hampir sepenuhnya didanai oleh masyarakat. ${ }^{20}$

Secara sederhana pendidikan dapat dipahami dari sudut pandang tingkatannya, namun pendidikan tinggi telah mendapat muatan makna yang di dalamnya mengandung berbagai hal

\footnotetext{
${ }^{17}$ HA.Mukti Ali Beberapa Madrasah Pendidikan di Indonesia (Yogyakarta : Yayasan Nida 1971) , 19

${ }^{18}$ Prof. DR.HM. Ridlwan Nasir,MA Mencari Tipologi Format Pendidikan Islam (PUSTAKA PELAJAR Yogyakarta $2005), 89$

${ }^{19}$ UU NO 20 tahun 2003

${ }^{20}$ Mujamil Qomar, Manajemen Pendidikan Islam (Jakarta: Erlangga, 2007), 101.
} 
yang perlu menjadi bagian dari keberadaan pendidikan tinggi dalam masyarakat dan bangsa. Menurut Barnet dalam Uhar Suharsaputra terdapat empat konsep penting tentang pendidikan tinggi, yaitu: "Higer education as a production of qualified human resources, higer education as a training for research career, higer education as a the efficient management of teaching provision, and higer education as a matter of extending life chance. "21

Pemahaman konsep di atas nampak bahwa pendidikan tinggi merupakan penghasil sumberdaya manusia yang berkualifikasi dengan keahlian tertentu, sehingga SDM yang dihasilkan akan memiliki kompetensi yang dapat berkontribusi bagi pembangunan masyarakat. Dalam pendidikan tinggi, pelatihan karir penelitian merupakan hal yang terjadi dalam prosesnya sehingga diharapkan pengembangan ilmu pengetahuan dapat terus terjadi serta dapat lahir ilmuwan bermutu yang dapat mengembangkan/berinovasi batas-batas pengetahuan.

Pendidikan tinggi juga merupakan penyedia pembelajaran dengan manajemen yang efesien sehingga pencapaian tujuan pendidikan dapat berjalan dengan baik, disamping itu pendidikan tinggi juga melakukan perluasan kesempatan hidup bagi mereka yang mengikutinya sehinga dapat berpartisipasi dalam pembangunan melalui pendidikan yang fleksibel dan berkelanjutan. ${ }^{22}$

Sementara itu menurut UU Pendidikan Tinggi, disebutkan bahwa Pendidikan Tinggi adalah jenjang pendidikan setelah pendidikan menengah mencakup diploma, program sarjana, program magister, program doctor, dan program profesi, serta program spesialis, yang diselenggarakan oleh perguruan tinggi berdasarkan kebudayaan bangsa Indonesia. ${ }^{23}$

Pengertian pendidikan tinggi menurut UU tersebut hanya menunjukkan jenis dari apa yang disebut pendidikan tinggi, meskipun dalam keseluruhan isi UU disebutkan berbagai hal yang perlu menjadi bagian pendidikan tinggi, sehingga empat konsep dan pengertian pendidikan tinggi tersebut pada dasarnya bersifat melengkapi dalam memberi kejelasan akan makna pendidikan tinggi/perguruan tinggi sebagai lembaga penting bagi peradaban umat manusia.

Perguruan tinggi sebagai penyelenggara pendidikan tinggi merupakan sub sistem dari sistem pendidikan nasional, perguruan tinggi adalah satuan pendidikan yang

\footnotetext{
${ }^{21}$ Uhar Suharsaputra, Manajemen Pendidikan Perguruan Tinggi, (Bandung: PT. Refika Aditama, 2015), 22.

22 Ibid. 23.

${ }^{23}$ UU no. 12 tahun 2012 tentang Pendidikan Tinggi.
} 
menyelenggarakan pendidikan tinggi. Dalam penyelenggaraan pendidikan dan pengembangan ilmu pengetahuan dan teknologi, maka perguruan tinggi berlaku kebebasan akademik dan kebebasan mimbar akademik serta otonomi keilmuan, serta perguruan tinggi memiliki otonomi untuk mengelola sendiri lembaga sebagai pusat penyelenggaraan pendidikan tinggi, penelitian ilmiah, dan pengabdian kepada masyarakat. ${ }^{24}$

Dalam konteks sistemik, perguruan tinggi sebagai lembaga formal yang menyelenggarakan pendidikan tinggi akan menentukan bagi keberhasilan pendidikan secara nasonal (makro) melalui kontribusi langsungnya pada berkembangnya pendidikan tinggi (messo) dengan pelaksanaan kewajiban perguruan tinggi dalam melaksanakan Tridharma pada masing-masing perguruan tinggi (mikro).

Dalam konteks jenjang pendidikan, perguruan tinggi menempati posisi teratas dimana peserta didik hanya bisa mengikutinya bila sudah menyelesaikan pendidikan dasar dan menengah, yang dalam konteks pendidika nasional dengan tingkat 'Angka Transisi' pada pendidikan yang lebih tinggi masih rendah, artinya masih banyak terdapat masyarakat yang tidak dapat menyelesaikan/mengikuti pendidikan di atasnya, dan hal ini merupakan tantangan yang harus disikapi dengan manajemen pendidikan perguruan tinggi yang efektif, efesien, dan bermutu dalam mengembangkan kemampuannya untuk makin mendorong dan memperluas kemampuan akomodir atas potensi mengikuti pendidikan yang masih terbuka luas.

Dalam konteks kesisteman dan juga kejenjangan dalam pendidikan formal, perguruan tinggi sebagai penyelenggara pendidikan tinggi masih memerlukan berbagai upaya dan kebijakan yang dapat meningkatkan angka melanjutkan masyarakat agar perannya makin meningkat dalam kuantitas dengan tetap mendasarkan pada peningkatan mutu berkelanjutan. $^{25}$

Fungsi Perguruan Tinggi merujuk pasal 58 Undang-undang nomor 12 tahun 2012 adalah:

1. Wadah pembelajaran Mahasiswa dan Masyarakat.

2. Wadah pendidikan calon pemimpin bangsa.

3. Pusat pengembangan Ilmu Pengetahuan dan Teknologi.

\footnotetext{
${ }^{24}$ UU no. 12 tahun 2012, Pasal 24.

25 Ibid. 25.
} 
4. Pusat kajian kebajikan dan kekuatan moral untuk mencari dan menemukan kebenaran.

5. Pusat pengembangan peradaban bangsa. ${ }^{26}$

Untuk mewujudkan fungsi-fungsi di atas, dalam pelaksanaan tridharma perguruan tinggi sebagai suatu keharusan yang dilaksanakan secara seimbang dalam melaksanakan pendidikan tinggi. Pelaksanaan fungsi proses yang bermutu akan mendorong pada terwujudnya fungsi dampak yang bermutu pula. Seluruh sivitas akademika dan pemangku kepentingan pendidikan tinggi harus mensinergikan perhatian dan dukungannya bagi terlaksananya proses yang bermutu, sehingga tuntutan akan dampak pendidikan yang signifikan bagi masyarakat akan benar-benar terwujud.

Dengan pengembangan dan penguatan fungsi-fungsi tersebut, pendidikan tinggi akan mampu mencapai tujuan pendidikan nasional melalui berbagai tingkatan tujuan yang telah direncakan dan ditetapkan sehingga pendidikan tinggi dapat mewujudkan tujuannya yaitu:

1. Berkembang potensi mahasiswa agar menjadi manusia yang beriman dan bertakwa kepada Tuhan Yang Maha esa dan berakhlak mulia, sehat, berilmu, cakap, kreatif, mandiri, terampil, kompeten, dan berbudaya untuk kepentingan bangsa.

2. Dihasilkannya lulusan yang menguasai cabang Ilmu Pengetahuan dan/atau Teknologi untuk memenuhi kepentingan nasional dan peningkatan daya saing bangsa.

3. Dihasilkannya Ilmu Pengetahuan dan Teknologi melalui penelitian yang memperhatikan dan menerapkan nilai Humaniora agar bermanfaat bagi kemajuan bangsa, serta kemajuan peradaban dan kesejahteraan umat manusia.

4. terwujudnya pengabdian kepada masyarakat berbasis penalaran dan karya penelitian yang bermanfaat dalam memajukan kesejahteraan umum dan mencerdaskan kehidupan bangsa. ${ }^{27}$

Tujuan-tujuan di atas pada dasarnya memperjelas apa yang menjadi kewajiban yang harus dilakukan perguruan tinggi perguruan tinggi yaitu tridharma yang esensinya menjadikan perguruan tinggi sebagai 'Center for excelence' dalam bidang pendidikan bangsa yang menghasilkan lulusan yang bertakwa, berakhlak mulia, sehat, berilmu, cakap, kreatif,

\footnotetext{
${ }^{26}$ UU no. 12 tahun 2012, Pasal 58.

${ }^{27}$ UU no. 12 tahun 2012, Pasal 5.
} 
mandiri, terampil, kompeten, dan berbudaya, serta menguasai Iptek; pengembangan penelitian sehingga menghasilkan ilmu pengetahuan dan teknologi; pengembangan pengabdian pada masyarakat dengan dasar nalar dan riset. $^{28}$

Dengan demikian, penguatan fungsi dan pengembangan perguruan tinggi menjadi suatu keharusan dalam mewujudkan tujuan dan proses pendidikan tinggi yang bermutu, baik dilihat dari segi proses, output, maupun outcome, bahkan dalam siatusi tertentu pengontrolan terhadap input pun perlu mendapat perhatian meskipun dalam banyak kasus, perguruan tinggi sering menghadapi kondisi dimana pengontrolan input cukup sulit dilakukan karena berbagai hal, namun demikian dengan input yang ada tetap proses pendidikan harus dilakukan secara profesional agar dampak pada output dan outcome dapat berhasil optimal, sehingga kemampuan lulusan perguruan tinggi dapat tetap menjadi bagian penting bagi tumbuh kembangnya peradaban bangsa dengan fondasi kekuatan moral dan kebenaran, serta kebajikan.

Jadi, perguruan tinggi dalam melaksanakan kewajiban, fungsi, tujuan, dan perannya harus mampu mengejewantahkan fungsi dan tujuan dalam suatu kerangka organisasi/kelembagaan perguruan tinggi. Oleh karena itu, perguruan tinggi perlu ditata, dikelola, dan dipimpin sesuai arah pendidikan tinggi yang diharapkan, serta mengacu pada prinsip profesionalitas sebagai ciri penting knowledge society.

Pendidikan tinggi hendaknya diselenggarakan dengan menggunakan prinsip-prinsip manajemen yang fleksibel dan dinamis agar memungkinkan setiap perguruan tinggi untuk berkembang sesuai dengan potensinya masing-masing dan tuntutan eksternal yang dihadapinya. Manajemen sering diartikan sebagai ilmu, kiat/seni, dan profesi. Lebih lanjut Nanang Fattah menjelaskan pandangan para ahli tentang manajemen, Luther Gulick mengatakan manajemen sebagai ilmu, karena manajemen dipandang sebagai suatu bidang pengetahuan yang secara sistematik berusaha memahami mengapa dan bagaimana orang bekerjasama. Follet dalam Fattah mengatakan sebagai kiat/seni, karena manajemen mencapai sasaran melalui cara-cara dengan mengatur orang lain menjalankan tugas.

Disisi lain, manajemen dipandang sebagai profesi karena manajemen dilandasi oleh keahlian khusus untuk mencapai suatu prestasi manajer, dan para profesional dituntut oleh

\footnotetext{
${ }^{28}$ Uhar Suharsaputra, Manajemen Pendidikan Perguruan Tinggi, (Bandung: PT. Refika Aditama, 2015), 28.
} 
suatu kode untuk mencapai tujuan tertentu yang telah dirumuskan sebelumnya. ${ }^{29}$ Pendidikan bermutu lahir dari sebuah proses panjang. Proses itu mencakup keseluruhan tahapan dalam sebuah tata kelola atau yang lebih masyhur (dikenal) dengan kata manajemen. Manajemen mutu telah lama menjadi kata yang booming (membumi) di banyak organisasi baik organisasi pemerintah maupun organisasi non-pemerintah (NGO). Beberapa ahli mendefinisikan manajemen sebagai berikut:

James A.F Stoner dan Charles Wankel mendefinisikan manajemen dengan istilah "The art of getting things done through people", dalam bahasa sederhana manajemen dapat didefinisikan sebagai seni mendapatkan sesuatu dengan memberdayakan sumber daya manusia yang ada. ${ }^{30}$ Luther Gulick dalam disertasi Latifah memahami manajemen sebagai pengetahuan sistemik dengan berusaha memahami mengapa dan bagaimana orang bekerja sama. Kata sistemik pada definisi Gulick ditafsirkan sebagai rangkaian kegiatan yang dilaksanakan secara teratur, tertib dan dengan tinjauan analisa segala macam resiko yang akan terjadi. $^{31}$

Menurut Moefti Wiriadihardja, manajemen adalah mengarahkan atau memimpin suatu daya usaha melalui perencanaan, pengorganisasian, pengkoordinasian dan pengendalian sumber daya manusia dan bahan ditujukan untuk mencapai tujuan yang telah ditentukan sebelumnya. $^{32}$ Sedang Syafaruddin mendefinisikan manajemen sebagai suatu proses pengaturan dan pemanfaatan sumber daya yang dimiliki organisasi melalui kerjasama para anggota untuk mencapai tujuan organisasi secara efektif dan efisien. ${ }^{33}$

Rchardus Djokopranoto dan Rchardus Eko Indrajit menjelaskan beberapa aplikasi fungsi manajemen umum dalam manajemen perguruan tinggi ada empat, perencanaan, pengorganisasian, penggerakan, dan pengawasan. ${ }^{34}$

Keempat fungsi tersebut dapat dijelaskan sebagai berikut:

\footnotetext{
${ }^{29}$ Nanang Fattah, Landasan Manajemen Pendidikan (Bandung: Remaja Rosdakarya, 2013), 1.

${ }^{30}$ James A.F Stoner dan Charles Wankel. Management (Third Edition), (Prentice Hall International, Englewood Cliffs, N.J. 1986), 3.

${ }^{31}$ Luther Gulick, Morphet dkk. "Efektivitas Manajemen Mutu Pesantren (Studi Kasus pada Pesantren Yayasan Bhakti Sarjana dan Pemuda Babakan, Pesantren Kebon Jambu Al-Islamy dan Pesantren Al-Ikhlas di Babakan Ciwaringin Kabupaten Cirebon Periode 2005-2010)”, dalam (Latifah, UPI Bandung: Disertasi Administrasi Pendidikan, 2012), 27.

${ }^{32}$ Moefti Wiriadihardja, Dimensi Kepemimpinan dalam Manajemen, (Jakarta: Balai Pustaka, 1987). 30.

${ }^{33}$ Syafaruddin, Manajemen Lembaga Pendidikan Islam( Jakarta: Ciputat Press, 2005), 42

${ }^{34}$ Rchardus Eko Indrajit dan Rchardus Djokopranoto, Manajemen Perguruan Tinggi Modern (Jakarta: tp., 2004), 49. dalam Peranan Manajemen Perguruan Tinggi Dan Implementasinya Di Fakultas Agama Islam (FAI) UNSIKA, Amiruddin, Passion of the Islamic Studies Center.
} 
Perencanaan. Perencanaan program kerja termasuk perencanaan anggaran, bukan merupakan hal yang baru bagi perguruan tinggi, baik perencanaan lima tahunan maupun perencanaan tahunan. Namun perencanaan perlu juga dilakukan untuk perencanaan strategis, yaitu perencanaan yang menentukan hidup matinya dan berkembang tidaknya suatu universitas.

Pengorganisasian. Fungsi pengorganisasian termasuk fungsi pengisian staf yang sesuai untuk setiap tugas atau kedudukan. Mengenai beberapa model organisasi perguruan tinggi. Mengenai pengisian staf atau karyawan, perlu dibedakan beberapa jenis karyawan yang bekerja di suatu universitas, yang masing-masing mempunyai tugas khas dan mempunyai karakteristik sendiri-sendiri. Ada sekurang-kurangnya empat jenis kelompok karyawan yang mempunyai tugas yang berbeda:

1. Karyawan akademi. Adalah para dosen dan para peneliti yang bertugas mengajar dan melakukan penelitian ilmiah.

2. Karyawan administrasi. Adalah karyawan yang bekerja di rektorat, keuangan, pendaftaran, personalia dan sebagainya.

3. Karyawan penunjang akademi. Adalah mereka yang bekerja sebagai ahli atau karyawan di perpustakaan, laboratorium, bengkel latihan, dan sejenisnya.

4. Karyawan penunjang lain. Adalah karyawan lain seperti sopir, tukang kebun, petugas pembersihan gedung, petugas pemeliharaan, dan sejenisnya.

Menurut Manullang, inti pengadaan sumberdaya manusia (SDM) adalah menyediakan tenaga kerja yang dibutuhkan suatu organisasi secara kuantitatif maupun kualitatif. Secara kuantitatif, ditentukan melalui analisis beban kerja (work load analysis) dan analisis angkatan kerja (work force analysis). Tenaga kerja secara kualitatif ditentukan melalui analisis jabatan (job analysis) yang menghasilkan, baik perincian tugas (job description) maupun spesifikasi tugas (job spesification). ${ }^{35}$

Qomar menyatakan bahwa tipologi manusia profesional-intelektual membutuhkan pelatihan, pendidikan, pengalaman dan keahlian yang diproses dalam waktu yang relatif panjang. Karena disamping terdapat unsur penanaman pengetahuan juga pembiasaan dalam kehidupan sehari-hari. Unsur penanaman mungkin dapat dicapai dalam waktu yang cepat,

\footnotetext{
${ }^{35}$ M. Manulang, Dasar-Dasar Manajemen (Yogyakarta: Gadjah Mada University Press., 2012), 201.
} 
tetapi pembiasaan membutuhkan proses berkesinambungan, sehingga diperlukan penguatanpenguatan akademis. ${ }^{36}$

Untuk penguatan akademis itu, Malik Fadjar melihat ada beberapa pemikiran praktis yang perlu diperhatikan berikut ini: $:^{37}$

1. Pemeliharaan dan peningkatan stabilitas kelembagaan. Dengan demikian, citra sebagai lembaga keilmuan melalui berbagai model dialog, komunikasi timbal balik, keterbukaan dan kebebasan yang bertanggung jawab tetap terjaga.

2. Pemeliharaan serta peningkatan sistem akademik dan kemahasiswaan. Dengan demikian, perguruan tinggi Islam dapat menjadi lembaga pendidikan tinggi yang menunjang pelaksanaan manajemen belajar-mengajar yang mantap, dengan melalui pembenahan serta pemenuhan berbagai sarana prasarana.

3. Menciptakan suatu model belajar privat (tambahan), yaitu "student day" (misalnya setiap Sabtu) sebagai model pengembangan daya kreasi dan apresiasi kehidupan kampus.

4. Pembentukan lembaga studi/kajian, seperti pusat studi islam, pusat penelitian, dan pusat pembibitan.

Pemberian keleluasaan pada tiap-tiap fakultas/jurusan untuk mengembangkan dan meningkatkan kegiatan kuliah tamu dan latihan-latihan keahlian dalam berbagai bidang, seperti bahasa, perpajakan, perbankan, dan sebagainya.

Penggerakan. Tugas penggerakan (actuating) adalah tugas menggerakkan seluruh manusia yang bekerja dalam suatu perusahaan agar masing-masing bekerja sesuai dengan yang telah ditugaskan dengan semangat dan kemampuan maksimal. Ini merupakan tantangan yang sangat besar bagi fungsi manajemen karena menyangkut manusia, yang mempunyai keyakinan, harapan, sifat, tingkah laku, emosi, kepuasan, pengembangan, akal budi dan menyangkut hubungan antar pribadi. Oleh karena itu, banyak yang mengatakan bahwa fungsi ini adalah fungsi yang paling penting dan juga paling sulit dalam keseluruhan fungsi manajemen.

\footnotetext{
${ }^{36}$ Mujamil Qomar, Manajemen Pendidikan Islam; Strategi Baru Pengelolaan Lembaga Pendidikan Islam (Jakarta: Erlangga, 2007), 106.

37 A. Malik Fadjar, 1998, Visi Pembaharuan Pendidikan Islam (Jakarta: Lembaga Pengembangan Pendidikan dan Penyusunan Naskah Indonesia (LP3NI), 1998), 178-179.
} 
Fungsi ini berada pada semua tingkat, lokasi, dan bagian perusahaan. Dalam fungsi ini termasuk memberikan motivasi, memimpin, menggerakkan, mengevaluasi kinerja individu, memberikan imbal jasa, mengembangkan para manajer dan sebagainya. Fungsi penggerakan kadang-kadang diganti dengan istilah lain misalnya fungsi kepemimpinan (leading). ${ }^{38}$

Pengawasan. Pengawasan adalah fungsi terakhir manajemen, namun bukan berarti yang paling kurang penting. Pengawasan adalah pengamatan dan pengukuran, apakah pelaksanaan dan hasil kerja sudah sesuai dengan perencanaan atau tidak. Kalau tidak, apa kendalanya, dan bagaimana menghilangkan kendala tersebut, agar hasil kerja dapat sesuai dengan yang diharapkan. Fungsi pengawasan tidak harus hanya dilakukan setiap akhir tahun anggaran, tetapi justru harus secara berkala dalam waktu yang lebih pendek, misalnya setiap bulan, sehingga perbaikan yang perlu dilakukan, tidak terlambat dilaksanakan. ${ }^{39}$

Peranan pendidikan tinggi dalam pengembangan sumber daya manusia dapat dicirikan pada tiga hal ;

1. Mencetak manusia yang bertanggung jawab. Menurut Azizi, bahwa ada kaitan antara fitrah, akhirat dan tanggung jawab. Setiap perbuatan pasti ada tanggung jawabnya yang berkonsekuensi di akhirat. Tanggung jawab tidak hanya sekedar administratif di dunia, tetapi lebih jauh secara substantif di akhirat. Melalui tanggung jawab inilah akan tercipta etika sosial, karena setiap tindakan dalam bentuk apapun akan memiliki nilai tanggung jawab baik dunia maupun akhirat.

2. Peran kebebasan berpikir. Kebebasan berpikir mengajarkan pada kita bahwa ilmu pengetahuan adalah sarana untuk membebaskan, dalam arti bahwa melalui kemampuan berpikir manusia diajarkan untuk menemukan (discovery) tentang sesuatu dalam bidangnya. Kebebasan dalam konteks ini adalah kebebasan untuk menemukan sesuatu, merevisi, atau menguatkan suatu dalil, teori dan konsep yang telah ada untuk kemaslahatan.

\footnotetext{
${ }^{38}$ Rchardus Eko Indrajit dan Rchardus Djokopranoto, Manajemen Perguruan Tinggi Moderen, 49.

${ }^{39}$ Ibid.
} 
3. Penguasaan terhadap kompetensi. Pendidikan harus mengarahkan peserta didik pada keahlian tertentu sehingga menjadi sarana untuk mengakses kehidupan. Oleh karena itu maka pendidikan tinggi harus dirancang untuk mewujudkan sarjana yang profesional sesuai dengan keahliannya. ${ }^{40}$

Upaya tokoh-tokoh Islam untuk memberdayakan umat Islam di Indonesia dalam jalur pendidikan juga diwujudkan dengan mendirikan perguruan tinggi Islam sebagai sebuah lembaga lanjutan. Upaya ini disempurnakan secara berkesinambungan mulai awal hingga sekarang dengan berbagai terobosan yang besrifat politis, kultural, sosial, maupun birokratik. Secara kualitatif, upaya tersebut dapat dinilai berhasil karena belakangan ini telah bermunculan berbagai perguruan tinggi yang berlabel Islam. ${ }^{41}$

Sementara itu, pelaksanaan pendidikan Islam tidak lepas dari peran serta masyarakat. Sebagian masyarakat di Indonesia masih memandang agama sebagai hal yang urgen dalam kehidupan. Oleh karena itu mengetahui dan memahami persoalan agama merupakan hal yang wajib. Maka wajar jika di Indonesia terdapat beberapa pesantren dan lembaga pendidikan Islam dengan jumlah santri yang relatif banyak. Kondisi seperti itu dapat menunjang kuantitas mahasiswa.

Sedangkan dalam kebijakan strategis perguruan tinggi Islam, menurut Feisal adalah: ${ }^{42}$

1. Membina dan memperbarui keimanan mahasiswa sesuai dengan ketentuanketentuan Islam yang bersumber kepada Al-Quran, As-Sunah, dan ijtihad atau pemikiran skolastik yang menggambarkan cara berfikir normatif dan berfikir deskriptif empiris;

2. Mengembangkan rasa, sikap, dan akhlak yang sesuai dengan nilai-nilai agama yang universal;

3. Mengembangkan kemampuan intelektual sehingga mampu berpikir ilmiah rasional dan logis;

Mengembangkan keterampilan-keterampilan tertentu untuk dapat secara nyata menyelesaikan masalah yang dihadapinya sehari-hari.

\footnotetext{
${ }^{40}$ A. Azizi Qadri, Pendidikan (agama) untuk Membangun Etika Sosial: Mendidik Anak Sukses Masa Depan: Pandai dan Bermanfaat (Semarang: Aneka Cipta, 2001), 122.

${ }^{41}$ Prof.Dr. Mujamil Qohar. Manajemen Pendidikan Islam. 9Erlangga 20020100

${ }^{42}$ Jusuf Amir Feisal, Reorientasi Pendidikan Islam (Jakarta: Gema Insani Press., 1995), 155.
} 


\section{Simpulan}

Lembaga pendidikan harus mengetahui dengan pasti apa yang dibutuhkan oleh peserta didik. Lembaga pendidikan hendaknya selalu berupaya mensinergikan berbagai komponen untuk melaksanakan manajemen mutu pendidikan yang dikelolanya agar dapat menjalankan tugas dan fungsi kependidikan. Untuk itu, kerjasama dengan semua komponen pendidikan dalam manajemen harus menjadi prioritas. Komponen pendidikan dimaksud adalah para pendidik, karyawan, peserta didik, orang tua/wali, maupun masyarakat.

Manajemen mutu dalam pendidikan merupakan cara mengatur semua sumber daya pendidikan, yang terorganisir dan terencana dalam pergerakan dan pengawasan yang terarah agar semua yang terlibat di dalamnya melaksanakan tugas dengan penuh semangat dan berpartisipsi dalam perbaikan pelaksanaan proses pendidikan sehingga menghasilkan mutu pendidikan yang sesuai harapan.

Setiap lembaga pendidikan harus mampu meningkatkan manajemen mutu sesuai dengan jenjangnya dan sesuai dengan kebutuhan peserta didik sehingga tercipta lulusan yang terbaik dan berkompetensi sehingga mampu terjun dalam kehidupan bermasyarakat dengan bekal ilmu yang dimiliki.

\section{Daftar Pustaka}

https//sites.google.com

Wiriadihardja, Moefti, Dimensi Kepemimpinan dalam Manajemen Jakarta: Balai Pustaka, 1987.

Syafaruddin, Manajemen Lembaga Pendidikan Islam Jakarta: Ciputat Press, 2005

Komariah Aan dan Tiratna Cepi, Visionary Leadership, Menuju Sekolah Efektif. Jakarta: Bumi Aksara, 2005.

Ali Mohammad, "Penjaminan Mutu Pendidikan" dalam Mohammad Ali, Ibrahim, R., Sukmadinata, N.S., Sudjana, D., dan Rasjidin, W. (Penyunting), Ilmu dan Aplikasi Pendidikan. Jilid II, Bandung: Pedagogiana Pres, 2007.

Mulyasa, E., Menjadi Kepala Sekolah Profesional, Bandung: PT. Remaja Rosdakarya, 2005. 
Ali Mukti Beberapa Madrasah Pendidikan di Indonesia ,Yogyakarta :Yayasan Nida, 1971

Nasir Ridlwan Mencari Tipologi Format Pendidikan Islam, Yogyakarta :Pustaka Pelajar, 2005 .

Surat Keputusan Bersama Tiga Menteri tahun 1975 bab III

UU NO 20 tahun 2003

Qomar Mujamil, Manajemen Pendidikan Islam Jakarta: Erlangga, 2007.

Suharsaputra Uhar, Manajemen Pendidikan Perguruan Tinggi, Bandung ; PT. Refika Aditama, 2015.

Fattah Nanang, Landasan Manajemen Pendidikan Bandung: Remaja Rosdakarya, 2013

Stoner James dan Wankel. Charles Management Third Edition, Prentice Hall International, Englewood Cliffs, N.J. 1986.

Gulick Luther, Morphet dkk. "Efektivitas Manajemen Mutu Pesantren (Studi Kasus pada Pesantren Yayasan Bhakti Sarjana dan Pemuda Babakan, Pesantren Kebon Jambu AlIslamy dan Pesantren Al-Ikhlas di Babakan Ciwaringin Kabupaten Cirebon Periode 20052010)”, dalam UPI Bandung: Disertasi Administrasi Pendidikan, 2012.

Wiriadihardja Moefti, Dimensi Kepemimpinan dalam Manajemen, Jakarta: Balai Pustaka, 1987.

Syafaruddin, Manajemen Lembaga Pendidikan Islam, Jakarta: Ciputat Press, 2005.

Indrajit Eko dan Djokopranoto, Manajemen Perguruan Tinggi Modern Jakarta: tp., 2004 dalam Peranan Manajemen Perguruan Tinggi Dan Implementasinya Di Fakultas Agama Islam (FAI) UNSIKA, Amiruddin, Passion of the Islamic Studies Center

Manulang M, Dasar-Dasar Manajemen, Yogyakarta: Gadjah Mada University Press., 2012.

Qomar Mujamil, Manajemen Pendidikan Islam; Strategi Baru Pengelolaan Lembaga Pendidikan Islam ,Jakarta: Erlangga, 2007.

Fadjar A. Malik, Visi Pembaharuan Pendidikan Islam, Jakarta: Lembaga Pengembangan Pendidikan dan Penyusunan Naskah Indonesia (LP3NI), 1998. 
Jurnal Keislaman, Vol 3, No 1

Qadrin A. Azizi Pendidikan (agama) untuk Membangun Etika Sosial: Mendidik Anak Sukses Masa Depan: Pandai dan Bermanfaat, Semarang: Aneka Cipta, 2001.

Qohar Mujamil, Manajemen Pendidikan Islam, Erlangga 2002.

Faisal Jusuf Amir, Reorientasi Pendidikan Islam, Jakarta: Gema Insani Press, 1995. 